\title{
1
}

\section{SCHOOL NURSING: EARLY BEGINNINGS AND THE UNFOLDING OF A NEW NURSING SPECIALTY}

JANICE LOSCHIAVO

\section{LEARNING OBJECTIVES}

- Recognize the historical role of women as caregivers.

- Define school nursing.

- Describe how school nursing evolved from public health roots.

- State three ways in which school nursing differs from other nursing subspecialties.

- Compare today's level of school health services with that of the past.

\section{Introduction}

The profession of school nursing has an exciting history. Commencing at the turn of the 20th century in an effort to support the requirement for mandatory school attendance, a group of astute women linked the horrific results of illness and poverty to school absenteeism and the profession of school nursing was born.

These women immediately recognized that help was needed to improve living conditions of poor, malnourished, immigrant families, so that children could attend school and become healthy, educated, American citizens.

Their story is that of:

- A new country which quickly recognized the need for children to be educated

- Brave, insightful women who made many sacrifices to help impoverished immigrants find a safe, healthy home in America

- Legendary nurses who courageously revealed inhumane living conditions and the pervasive impact of poverty 
- Seldom-acknowledged heroes like Lillian Wald who fought politicians and advocated tirelessly for maltreated children

- Insightful pioneers such as Lina Rogers, our first school nurse who, through education, created an atmosphere of acceptance and wellness so children could learn and thrive

- The emergence of a new nursing specialty, grounded in public health principles

- The school nurse of today who upholds our founders original goal to help each child attain the highest level of wellness

In this chapter, you will learn how nursing grew out of women's position as caregiver in the home and evolved into a larger role within the community. Once women were recognized outside of the home as competent caregivers, they quickly were also accepted as pioneers in the healthcare delivery system. Armed with an historical insight, today's school nurse can once again take up the challenge to create greater opportunities and a better world for our children.

Now, meet the heroes of our profession whose work will inspire you. Join those who came before us by adding your contribution as the story of school nursing continues to unfold. It is hoped that you will be motivated by their accomplishments. Although books may not be written about you, each and every one of you will be called upon to do work that is extraordinary.

\section{Our History: Women as Nurturers and Caregivers}

\section{Early Beginnings}

If one looks back on the history of caring for the ill, it is apparent that women have always assumed the responsibility for healing. With no formal education available and spurred on solely by intuition and observations, women delivered babies, cared for sick children, and tended to the elderly and those in need within the home setting. Nursing was considered a natural extension of motherhood (Joel, 2018, pp. 3-7).

First reports of nursing go back to the Romans in $300 \mathrm{AD}$, who attempted to have a hospital in every town under the rule of the Empire. Nurses were known to work alongside doctors. As Rome came under the Byzantine Empire, hospitals were created in Constantinople. These early hospitals were known to have both male and female nurses (Nursing School Hub, n.d.)

\section{The Middle Ages}

The development of the nursing profession has been heavily influenced by religion and wars (Wold, 1981, pp. 4-18). Starting around 500 AD, hospitals existed in Merida, Spain, that were run by Catholic priests. These early institutions cared for all 
people, regardless of nationality or religion. From the 10th to 11th century, nursing expanded and monasteries began to house hospitals on their premises.

During the years from 1500 to 1850 , nurses were often viewed as wayward women. Some who were poor or homeless were offered positions as nurses in lieu of going to jail. Those without immediate family or caring relatives became nurses. Lacking a family or home of their own, this left them with little choice. Nursing was seen as dirty work and the lowest of positions in the social hierarchy.

During the Middle Ages, early Christians viewed nursing care as an act of mercy and expression of faith. Women of religious and secular orders tended to the sick in institutional settings. Churches built adjacent hospitals, and nuns cared for the sick and dying.

\section{The Age of Modern Nursing}

Florence Nightingale, the lady with the lamp, earned her title from nightly checks on soldiers injured in the Crimean War of 1854. A well-educated daughter of wealthy British parents, Nightingale chose to become a nurse despite the strong social convention that asserted this was not a respectable career for well-bred ladies (D'Antonio, n.d.) She later went on to open a school to train women to care for men in battle.

Born in 1820, Florence Nightingale became an English social reformer and the founder of modern nursing. Authoring over 150 books, she is credited with making hospitals cleaner and safer. Nightingale is also acknowledged as the creator of the first PIE Chart for nursing: Problem, Intervention, and Evaluation (Alexander, 2018).

Today we have modified PIE and use the Nursing Process: Assessment, Diagnosis, Planning, Implementation, and Evaluation.

It is believed that modern nursing in the United States commenced in 1873, when the first three training schools for nurses opened in an attempt by women reformers to formalize training and pass on their knowledge. These women were looking for meaningful work, which led to a new healthcare professional-the trained nurse.

\section{The Age of Nurse's Training}

As the United States' population grew in numbers, so likewise did their health needs. Many hospitals were still affiliated with religious groups and established their own schools in order to staff an ever growing number of patients. Schools developed under the control of hospitals where nurses learned by a hands-on approach to caring. In exchange for lectures and clinical instructions, students provided hospitals with skilled, free nursing care while they trained, usually for several years. Prospective nurses were housed in a residence located on the hospital grounds, and daily hospital duties were part of their nursing preparation.

Upon completion of a prescribed program, the student nurse was permitted to take a state examination, passage of which certified the candidate as a registered nurse 


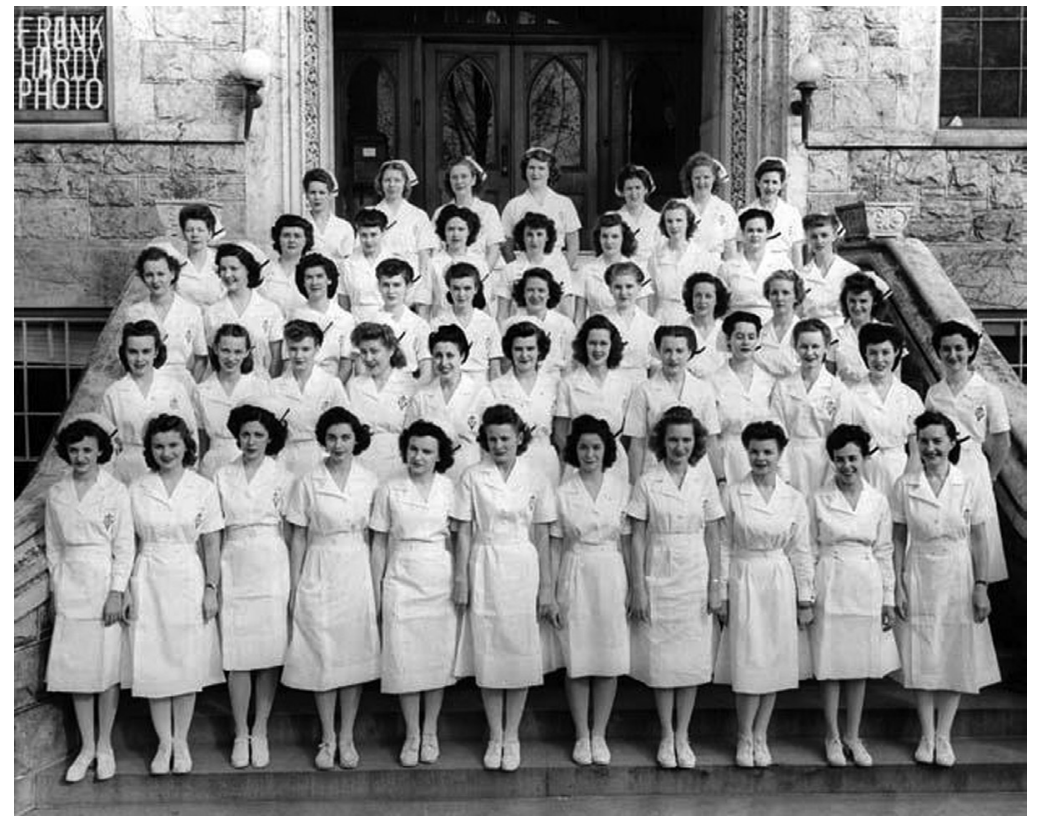

FIGURE 1.1 Sacred Heart School of Nursing Graduates, Pensacola, Florida (1947). SOURCE: Courtesy of Frank Hardy Photography.

in that state. After being properly trained and passing the exam, the student usually remained at the hospital that prepared her and served as a staff nurse (Figure 1.1).

Once training was completed, nurses proudly donned their caps, white uniforms, shoes and stockings set about to care for those in need and begin their career as a professional nurse.

\section{The Age of Educational Preparation}

Today, nurses attend a college or university to obtain an associate's or bachelor's degree in nursing. Hospital experience is not as extensive in the preparation. Much of the bedside care is rendered by health assistants with the nurse supervising or preparing to work in specialty areas of the hospital.

The 20th century paved the way for a more expanded role and introduced distinct areas of specialization for nurses. Entering as a nurse with general preparation means further educational preparation is needed if one wishes to go on to specialize in one field of nursing. This usually occurs at the bachelor's or master's level.

As with most professions, specialization is the current way. The nurse who chooses to work exclusively in one area must seek additional educational preparation before doing so. Such is the specialty of school nursing. 


\section{Today's Nursing Profession}

From these humble beginnings, the profession of nursing has grown in staggering leaps. Nursing is now the largest and most diverse of all healthcare professions. With true demographic representation remaining an elusive goal, nursing does have a higher proportional representation of racial and ethnic minorities than other healthcare professions (D’Antonio, n.d.).

In 2019 , for the 18th consecutive year, nurses were voted as the most trusted professionals (Daily Nurse, 2020). Mother Teresa, our most famous nurse of modern times, eloquently stated, "the world's problems have risen because we all recognize a family that is too small." As nurses, we include many more in our families. We make our circle much larger as we care for strangers with the same devotion our predecessors gave solely to family members.

Today nurses no longer wear white caps and uniforms. These have been replaced with lab coats, slacks, and pins. Moreover, more men are becoming registered nurses and, fortunately, all ethnic groups are growing in representation. Instead of a capping ceremony, graduation program consists of a pinning signifying completion of the course of study.

The nurse of today is a registered professional nurse who most likely holds a bachelor's degree. Today's nurse is better educated than ever and is seen as a leader in a hospital or any chosen health field. In most instances, the nurse will select an area of specialty to focus on such as school nursing.

\section{Definition of School Nursing}

The Board of Directors of the National Association of School Nurses gives us the following definition:

School nursing, a specialized practice of nursing, protects and promotes student health, facilitates optimal development, and advances academic success. School nurses, grounded in ethical and evidence-based practice, are the leaders who bridge healthcare and education, provide care coordination, advocate for quality student-centered care, and collaborate to design systems that allow individuals and communities to develop their full potential. (Adopted by the NASN Board of Directors, February 2017)

\section{A History of School Nursing: The Path to and from Henry Street}

School nursing began to appear in Europe as early as 1892. As educational opportunities were made available to all, schools and student enrollment grew. Once children gathered, it did not take long to recognize that malnourishment and/or illness and the ability to learn were linked. In order for children to learn, they had to be in school and well. Absenteeism could not be corrected without looking at the underlying causes.

Amy Hughes, the first European school nurse was hired in London in 1892. Her job was to investigate the nutritional status of school children (Table 1.1). Once the 


\section{TABLE 1.1 SCHOOL NURSING HISTORICAL TIMELINE}

\begin{tabular}{|c|c|}
\hline 1892 & $\begin{array}{l}\text { London } \\
\text { Amy Hughes is hired to investigate the nutritional status of schoolchildren } \\
\text { in the school setting. This is the first recorded employment of a school } \\
\text { nurse. }\end{array}$ \\
\hline 1893 & $\begin{array}{l}\text { Belgium } \\
\text { Brussels is the first city to employ a school physician and establish orga- } \\
\text { nized, citywide inspection of schools. }\end{array}$ \\
\hline 1894 & $\begin{array}{l}\text { Boston } \\
\text { School health services are initiated to identify and exclude students with } \\
\text { serious communicable diseases, such as pertussis, measles, mumps, scarlet } \\
\text { fever, and parasitic diseases, including lice, ringworm, and scabies. }\end{array}$ \\
\hline 1902 & $\begin{array}{l}\text { New York } \\
\text { The Henry Street Settlement is organized, modeled after an English pro- } \\
\text { gram. Lillian Wald, head nurse, appoints Lina Rogers as the nation's first } \\
\text { school nurse. The goal is to decrease absenteeism following implementa- } \\
\text { tion of mandatory school attendance. Between } 1902 \text { and } 1903 \text { the number } \\
\text { of absentees decreases from 10,567 to 1,101. Twenty-five more nurses are } \\
\text { then hired and paid by the New York City Board of Education. }\end{array}$ \\
\hline $1920 \mathrm{~s}$ & $\begin{array}{l}\text { This decade sees the expansion of the school nurse's role. Health education } \\
\text { is added and medical examinations begin in schools to identify physical } \\
\text { defects. }\end{array}$ \\
\hline $1930 \mathrm{~s}$ & $\begin{array}{l}\text { Individual states begin to require specific education for school nurse prac- } \\
\text { tice. }\end{array}$ \\
\hline 1940s & $\begin{array}{l}\text { With war present in much of the world, leaders in the United States realize } \\
\text { the importance of the maximum degree of health for all to serve in the } \\
\text { armed forces and support the country at home. Health as a school subject } \\
\text { begins to include an emphasis on physical fitness. Educators recognize the } \\
\text { correlation between health teaching and practice. }\end{array}$ \\
\hline $1950 \mathrm{~s}$ & $\begin{array}{l}\text { The role of the school nurse is expanded to focus on prevention. Screen- } \\
\text { ings in dental health, vision, and hearing are followed up and fewer stu- } \\
\text { dents are left with chronic diseases. Health counseling is introduced. }\end{array}$ \\
\hline 1960 & Some states require nurses to have teaching degrees. \\
\hline 1965 & $\begin{array}{l}\text { Federal laws begin to take shape, ensuring that all children, whether } \\
\text { handicapped or not, are to be appropriately educated. These laws further } \\
\text { strengthen the position of the school nurse, whose presence now is re- } \\
\text { quired to perform treatments and give medications in the school setting. } \\
\text { These laws continue to be revised, renamed, and enhanced to further } \\
\text { benefit all children with special needs. }\end{array}$ \\
\hline 1968 & $\begin{array}{l}\text { The NEA establishes the DSN. A nationwide survey is conducted to } \\
\text { establish school nurse credentials for each state. The DSN begins to form } \\
\text { committees, develop policies, and elect officers. }\end{array}$ \\
\hline 1979 & $\begin{array}{l}\text { The DSN separates from NEA to form the NASN, which now serves as the } \\
\text { hub for all the state organizations. }\end{array}$ \\
\hline
\end{tabular}


TABLE 1.1 SCHOOL NURSING HISTORICAL TIMELINE (CONTINUED)

\begin{tabular}{|l|l|}
\hline Today & $\begin{array}{l}\text { School nursing continues to flourish as a separate discipline. Through } \\
\text { NASN, school nurses partner with national health organizations, publish } \\
\text { a journal and reference books, formulate position statements, and hold } \\
\text { nationwide conventions to disseminate information and foster communica- } \\
\text { tion. NASN also employs a Washington, DC-based representative to lobby } \\
\text { for school nursing issues and interact with Congress on the organization's } \\
\text { behalf. }\end{array}$ \\
\hline
\end{tabular}

NASN, National Association of School Nurses; NEA, National Education Association; DSN, Department of School Nurses.

SOURCE: Reproduced from Loschiavo, J. (2019). Fast facts for the school nurse (3rd ed., pp. 8-9). New York, NY: Springer Publishing Company.

awareness was raised in Europe, those who were receptive, were ready to take action in the United States.

In 1894, the city of Boston began to recognize the seriousness of communicable disease in children and made efforts to exclude students with symptoms of illness. Shortly after that, New York City also sought to address the problem of school illness and the resulting absenteeism.

\section{The Henry Street Settlement}

Between the years 1880 and 1920, approximately 19 million immigrants arrived in New York City. Most settled on the east side, and were poor, malnourished, lived in squalid, deplorable conditions. Illness was rampant and people suffered and died due to poor living accommodations.

The Henry Street Settlement was the idea of Lillian Wald (1867-1940), one of the most influential and respected humanitarians and social reformers of the 20th century (Henry Street Settlement, n.d.). Born into a wealthy family of Jewish professionals, Wald was a trained nurse and a visionary.

Lillian Wald developed a community-based nursing practice on the Lower East Side of New York City where the need was greatest. She hand-picked a small group of nurses capable of working independently. Lina Rogers was one of them. Lillian Wald and Lina Rogers, both prominent women, are credited with bringing nurses into schools in the United States.

Not only was Wald a dedicated nurse, but she also proved be a savvy politician. Wald recognized the needs of people and knew how and where to go to make things happen. Her awareness came about by accident.

In March of 1893, Lillian Wald was just 25 years old and a student enrolled in the Women's Medical College. Wald was in the middle of teaching a class to immigrant mothers at the Louis Technical School on the Lower East Side of New York City when a little girl interrupted crying, begging for help for her mother. Wald followed the girl 
to her home on Ludlow Street. Entering the tenement, Wald noted courtyard outhouses, with missing doors and overflowing with feces. She located the apartment the family lived in and was appalled to learn that it was also inhabited by other families who shared rooms at different times of the day.

Wald saw that the young mother had hemorrhaged while in labor and been abandoned by her doctor, due to her inability to pay his fee.

Wald called the experience her "Baptism of Fire." She was ashamed to live "in a society that permitted such conditions to exist" (Levine, 2018).

At that time, there was no such thing as shelters. The homeless went to police stations. There were no child labor laws or playgrounds and little access to clean milk or pure water. One out of 10 infants died. School was not mandatory and many small children were kept at home to care for infants so both parents could work. Poverty caused the inhumane living conditions and the living conditions caused disease. Wald recognized that she was not only dealing with the illness but the conditions which caused it.

Wald knew then what most people were totally unaware of, that she not only had to help the sick patient but must also first address poverty and the social issues that caused the diseases and illness.

Wald wrote: Tuberculosis was "pre-eminently a disease of poverty, and can never be successfully combatted without dealing with its underlying economic causes: bad housing, bad workshops, undernourishment and so on" (Wald, Henry Street Settlement).

Little government support was offered and many maintained the illusion that poor were poor because of their own moral failures. The attitude of officials was one of indifference and arrogant condemnation.

As a political activist, Wald firmly believed that a democratic government must first help to alleviate poverty. She saw and understood that social justice work was democracy in action and maintained that working as a nurse on the Lower East Side was a way for her to "assert by deed [her] faith in democracy."

Lillian Wald moved into the Lower East Side neighborhood and lived and worked among the impoverished. The nurses charged patients on a sliding scale according to what they could pay. The nurses' residence became known as the Henry Street Settlement. Besides providing nursing services, Wald's nurses gave English language lessons, served meals, provided music enrichment classes, and made a safe playground in the yard for children. Wald pioneered what we know now as public health nursing, strived for housing reform, supported the movement for the advancement of colored people, fought for world peace and women's rights, and emerged as a political leader (Figure 1.2).

"Our basic idea was that the nurse's peculiar introduction to the patient and her organic relationship with the neighborhood should constitute the starting point for a universal service to the region... We planned to utilize, as well as to be implemented by all agencies and groups of whatever creed which were working for social betterment, private as well as municipal. Our scheme was to be motivated by a vital sense of the interrelation of all these forces. We consider ourselves best described by the term public health nurses." (Wald, Henry Street Settlement) 


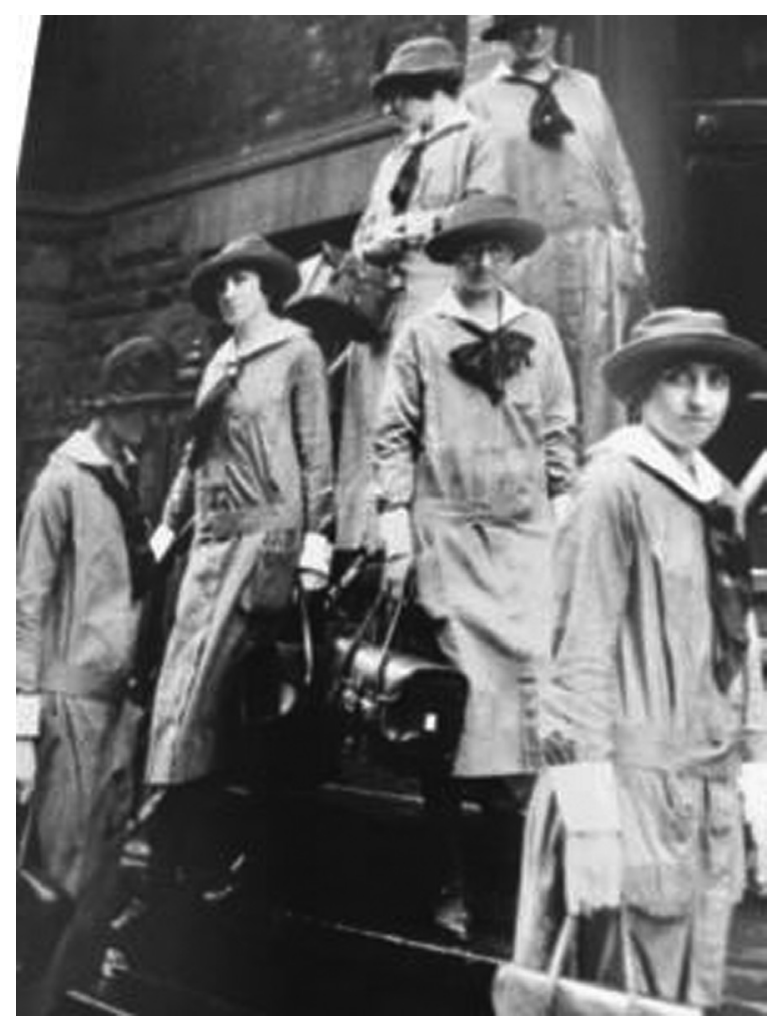

FIGURE 1.2 The Henry Street Settlement, First Public Health Nurses, Circa 1902. SOURCE: Getty Images/Bettmann.

\section{The Challenge}

In 1897, the city of New York hired 150 physicians to help control the large number of school absentees. They examined and excluded children with cases of lice, impetigo, and tuberculosis. By excluding quickly, it was hoped that the child would recover, not further spread disease, and be able to return to a healthier school environment sooner (Working Nurse, 2019). This attempt proved to be totally ineffective. Once home, children never returned to school. Diseases continued to spread since many families could not afford medical care, were severely malnourished, and remained living in crowded conditions.

In 1902, an article appeared in the American Journal of Nursing identifying the major problem to the New York City Board of Health and Board of Education. An experiment was to be conducted to address the large number of children absent from school. School attendance had become mandatory yet many children did not attend school. Wald offered the services of one of her nurses, Lina Rogers, to address the absentee problem. 
Thus, on October 1, 1902, after the failure of the physicians to decrease absentee rate, Lina Rogers was placed in the school setting. Rogers was assigned to the four schools with the highest level of absenteeism, a total of over 10,000 children. An agreement was struck with the city officials that if Rogers succeeded in reducing absenteeism, the city would henceforth pay for nurses to be placed in schools.

In 1 month, the absentee rate was significantly decreased. Within 6 months, absenteeism fell by $90 \%$ and 27 more nurses were assigned to New York City schools.

Lina Rogers succeeded because she developed formal protocols for various health issues and carefully documented nursing interventions. She wrote in her journal:

A sensible school nurse, with good judgment, discretion and enthusiasm, may be a powerful factor in the general improvement of a community. (Hanink, 2019)

In 1914, Rogers married one of the school physicians, William Struthers, and in 1917, she authored the first school nurse textbook, The School Nurse: A Survey of the Duties and Responsibilities of the Nurse in Maintenance of Health and Physical Perfection and the Prevention of Disease Among School Children. Her introduction states:

School nursing is still in its infancy, and many changes in methods are to be expected, but the underlying essentials - child love and preservation of child health - will exist as long as child life.

Now declared a National Historic Landmark, the Henry Street Settlement is recognized as laying the foundation for child labor laws, playground construction, battered women's shelter, transitional housing for the homeless, mental health services, senior citizen lunch programs, and many other services the poor benefit from today.

\section{School Nursing Today}

As you ponder the accomplishments of those who came before us, do not do so in terms of our world as it exists today. One must bear in mind that the 19th Amendment of the Constitution which granted women the right to vote, was not passed until 1920. Our female predecessors not only were founding mothers but political activists who made their voices heard decades before women had any status.

Today, many states can boast a school nurse in almost every school. All teach one-on-one with students and serve as the health expert in their respective schools. Many school nurses are also certified teachers of health and have formal, teaching schedules.

There is a State School Nurses Association in each of the 50 states and, in 1979, the National Association of School Nurses (NASN) was organized. NASN serves as the hub for all state organizations as well as providing numerous educational programs, formulates position papers, offers professional journals, and sets the standards for all school nurses through the Framework for 21st Century School Nurse Practice. 
Today's school nurse recognizes that we should not only care for people when they are ill but that the real power lies in our ability to change unhealthy lifestyle choices through education. Pain, disease, and illness, in many instances, can be lessened or totally prevented.

\section{Legislation Impacting Schools}

The role of the school nurse was significantly impacted by legislation supporting those children with special needs. No longer ignored, these children now have rights. The school nurse is involved with seeing that the laws are implemented.

The Individual with Disabilities Education Act is a federal law that protects students with disabilities. Adopted in 1975 and amended in 2004, the law clearly states that every child is entitled to a Free Appropriate Public Education (FAPE). Provisions include:

- Emphasis must be placed on those children with disabilities and providing them with related services.

- Children must receive appropriate evaluations by a team of knowledgeable and trained evaluators.

- Each child must have an Individualized Education Plan to ensure access to a FAPE.

- Children must be placed in the least restrictive environment.

- All efforts must be made to keep the child in a general education setting.

- Classroom modifications, teaching aids, and alternate methods must be explored.

- If classroom presence proves inappropriate, with parental participation, other placements can be explored (Saleh, n.d.).

No longer isolated in special schools, more children now receive medications and treatments in the mainstream school setting. This can only be accomplished by the school nurse. The school nurse plans their care so all, regardless of need, have a place in the school community.

\section{Current Issues Facing School Nurses}

Recognizing that the specialty of school nursing continues to evolve, there are a number of issues that confront the school nurse of today. These include:

\section{Lack of Uniform, State, Educational Requirements}

Since passage of the 10th Amendment to the Bill of Rights in 1791, all aspects of education are left to the individual states to determine. Some states require school nurses to have a bachelor's degree in nursing and certification. Other states may only require a few courses in child development to qualify as a school nurse. There is no continuity in requirements. This creates confusion 
as nurses frequently move from one state to another. The better educated the nurse is the better prepared to teach and render care.

\section{Poor Pay}

In many instances, the school nurse will be paid on a teacher's salary guide. Usually, this is far less than hospital wages. After completing a program of study to become a school nurse, the nurse will be faced with greater responsibility for far lower pay.

\section{Growing Number of Medically Fragile Students}

Since passage of the Individuals with Disabilities Act (1973), children with chronic conditions needing medications and/or treatments are part of the mainstream. Children with diabetes, severe allergies, seizure disorders, etc., require intense planning and care in order to allow them to blend into the mainstream and learn in the least restrictive environment. Only the school nurse can make this happen. These plans necessitate a working knowledge of the health issue and require many hours of intense preparation.

\section{Resistance of Parents to Immunize Children}

The school nurse is the gatekeeper for immunization requirements. Until the child registers for school, parents can choose not to immunize. Since there are a growing number of children unprotected against highly communicable diseases, the school nurse must be alert to protect all students. Religious, medical, and/or philosophical exemptions are granted in most states.

\section{Acceptance of the Needs of the Marginalized Child}

Today, nurses have a greater awareness of the student who is marginalized because of the challenges they face. These include students who are mentally ill, transgender, culturally different, dependent on illegal substances transient, morbidly obese, etc. Moreover, teachers are not always prepared to deal with issues as they develop in the classroom. The school nurse must be cognizant of these special needs children and work to help them find their place in the school community.

\section{High Risk Area}

For the most part, the school nurse works independently. In almost all other nursing settings, nurses work as part of a team so if a difficult decision must be made, the team or someone in charge will make the decision. Also, when a shift is completed, another nurse comes in to pick-up where the prior nurse left off. Additionally, in school nursing, you make decisions with little or no diagnostic tools. 
The school position involves many varied tasks including nursing, teaching, record- keeping, medications, treatments, and health counseling, all high risk areas. Even the smallest error can be libelous if misconstrued.

\section{No Substitutes}

School nurses will report that this is their number one concern. Qualified substitutes are almost nonexistent. If one does manage to recruit a substitute, most likely that person will quickly be offered a full-time position.

Substitute pay is comparable to what teachers get which is far less than the nurse can make per diem in a hospital setting or through an agency.

\section{Summary}

To know the history of the nursing profession is to know the foundation on which school nursing was built. To know the foundation is to know how necessary it is to continue to affirm and grow our profession.

Recognized as the most trusted profession, nursing carries tremendous responsibilities and challenges as well. School nursing will provide unique opportunities through education to make significant changes in lifestyle which will continue to have a lifetime impact on children.

This is an exciting time for school nursing. Our role is broader and encompasses much more than ever (NASN Framework, 2018).

The school nurse of today possesses innate qualities which identify and separate us from other nursing specialties. Walking proudly with one foot in nursing and the other in education, we recognize the importance of teaching and community involvement. This common thread, when accepted and affirmed, will allow all of us and our school nursing profession to grow and flourish for many years to come.

\section{References}

Alexander, K. (2018). Florence Nightingale. Woman's history museum. Retrieved from www .womanshistory.org

D’Antonio, B. (n.d.). Nursing medical profession. Retrieved from https://www.britannica .com/science/nursing

Daily Nurse. (2020) Gallup's 2019 most trusted professions. Retrieved from dailynurse .com/gallups-2019-most-trusted (2020)

Hanink, E. (2019). Lina Rogers, the first school nurse. Providing healthcare to keep kids in school. Working Nurse. Retrieved from https://www.workingnurse.com/articles/lina -rogers-the-first-school-nurse

Henry Street Settlement. (n.d.). Lillian Wald. Retrieved from https://www.henrystreet.org Joel, L. (2018). Advanced practice nursing (pp. 3-7). Philadelphia, PA: F.A. Davis Company. 
Levine, L. (2018, November). Lillian Wald's lower east side: From visiting nurse service to the Henry Street Settlement. Retrieved from https://www.6sqft.com/lillian-walds-lower -east-side

Loschiavo, J. (2019). Fast facts for the school nurse (3rd ed., pp. 8-9). New York, NY: Springer Publishing Company.

National Association of School Nurses. (2016). Definition of school nursing. Retrieved from https://www.nasn.org/advocacy/aboutnasn

National Association of School Nurses. (2018). Framework for 21st century school nursing practice. Retrieved from https://www.nasn.org/nasn/nasn-resources/professional-topics /framework

Nursing School Hub. (n.d.). The history of nursing. Retrieved from www.nursingschoolhub .com

Rogers, L. (1917). The school nurse: A survey of the duties and responsibilities of the nurse in maintenance of health and physical perfection and the prevention of disease among school children. New York, NY: G.P. Putnam's Sons.

Saleh, M. (n.d.). Smart kids, your child's right: 6 principles of IDEA. Retrieved from www .smartkidswithld.org

Wold, S. (1981). School nursing: A framework for practice (pp. 4-18). Minnesota, MN: Sunrise River Press.

\section{Further Readings}

Ehrenreich, B. (1973). Witches, midwives, and nurses; A history of women healers. Old Westbury, NY: The Feminist Press.

Hallet, C. (2010). Celebrating nurse: A visual history. London, England: Barrons. 